\title{
РОЛЬ «ІМПЕРАТОРА» ТА «МІСТА-СТОЛИЦІ ЯК СОЦІАЛЬНОЇ СТРУКТУРИ У СИМВОЛІЧНИХ РИТУАЛАХ У РОМАНІ САЛМАНА РУШДІ «ФЛОРЕНТІЙСЬКА ЧАРІВНИЦЯ»
}

\author{
Христина Дрогомирецька
}

\author{
Аспірант, \\ Кафедра світової літератури, \\ Львівський національний університет імені Івана Франка (УКРАЇНА), \\ 79000, м. Львів, вул. Університетська 1, \\ e-mail: Joann@i.ua
}

\begin{abstract}
PЕФЕРАТ
Мета. У статті розглянуто роль «імператора» і «міста-столиці» у конструюванні символічної структури роману Салмана Рушді «Флорентійська чарівниця». Дослідницька методика. Особливості моделювання топосу в романі Рушді означено на основі концепції хронотопу Михайла Бахтіна. У статті також використано ідеї П’єра Бурдьє, Мішеля Фуко і Гі Дебора щодо міста як певної соціальної структури, для розвитку якої важливі виконання ритуалів. Результати. Місто в романі «Флорентійська чарівниця» проаналізовано як соціальну структуру і символічну систему, яка провокує ієрархічні зв'язки, що вибудовуються у межах конкретного топосу «міста-столиці». Ієрархія столиці як «капіталу» імперії найяскравіше відображена в імператорському палаці: імператор $є$ хранителем капіталу і тим, хто розподіляє «блага». Проте поява дзеркальних образів-двійників із суміжними функціями приводить до кризи розрізнення і домінування ототожнення, а відтак руйнування цілісності соціальної системи. Наукова новизна. Твори Рушді здебільшого розглядають крізь призму мультикультуралізму, досліджуючи проблеми взаємин рідної та чужої культур, а також способи поєднання історичного факту i художнього вимислу, проте у цій науковій розвідці важливим було розробити інший вектор дослідження, що дозволяє розкрити приховані смисли авторського художнього світу. Практичне значення. Матеріал статті може бути використаний при подальшому вивченні творчості Рушді і новітньої британської літератури.
\end{abstract}

Ключові слова: символічна система, топос, імператор, місто-столиця, капітал, Салман Рушді.

THE ROLE OF THE «EMPEROR» AND «CAPITAL CITY» AS A SOCIAL STRUCTURE IN THE SYMBOLIC RITUALS IN THE NOVEL
BY SALMAN RUSHDIE «THE ENCHANTRESS OF FLORENCE»

\section{Christine Drohomyretska}

\author{
Postgraduate student, \\ Department of World Literatura, \\ Ivan Franko National University of Lviv (UKRAINE), \\ 79000, Lviv, 1, Universytetska str., \\ e-mail: Joann@i.ua
}

\begin{abstract}
Aim. The article considers the role of the «emperor» and the «capital city» in the construction of the symbolic structure of Salman Rushdie's novel «The Enchantress of Florence». Methods. The features of topos modeling in Rushdie's novel are defined on the basis of Mikhail Bakhtin's concept of chronotope. The article also uses the ideas of Pierre Bourdieu, Michel Foucault and Guy Debord concerning the city as a specific social structure which functioning depends on rituals. Results. The city in «The Enchantress of Florence» is analyzed as a social structure and symbolic system, provoking hierarchical relations constructed within the specific topos of the «capital city». The hierarchy of the capital city as the «capital» of the empire is clearly reflected in the image of emperor's palace: the emperor is the keeper of the capital and the distributor of the «good». However, the appearance of mirror images with adjacent functions leads to the loss of distinctions and the dominance of identification, that is, the destruction of the integrity of the social system. Scientific novelty. Rushdie's work is
\end{abstract}


mostly studied from the perspective of multiculturalism, examining the problems of interaction between native and alien cultures, of the combination of fact and fiction. Therefore, in this survey, it was important to develop a different vector of research, allowing to reveal the hidden meanings of the author's artistic world. Practical meaning. The material of the article can be used for the further study of Salman Rushdie's works and the contemporary British literature.

Key words: symbolic system, topos, emperor, capital city, capital, Salman Rushdie.

Соціальна структура міста у романі сучасного британського письменника Салмана Рушді «Флорентійська чарівниця» («The Enchantress of Florence», 2004) художньо репрезентована через образи двох міст: Флоренції та Сикри. Представлена через розповіді чужинця, Флоренція виступає радше метатопосом, тоді як Сикра - місто-столиця імператора моголів Акбара - центральним топосом, що реалізує авторську візію моделювання і символічного функціонування художнього простору в романі. Саме на прикладі образу Сикри можна простежити, як метафоризується простір для того, щоб виступати цілісним явищем у свідомості суб'єктів, що представлені персонажами роману. Чітка ієрархія міста-столиці Сикри, на чолі якого імператор Акбар, - це своєрідна символічна система, у якій імператор виконує певні сталі функції. Виключно завдяки цьому перформативу система і може вважатися ліквідною. Крім того, саме імператор концентрує у собі найбільший привілей чи найбільше благо i розподіляє певні ролі між своїми підданими. Акбар може як наближати деяких суб'єктів до себе, тобто до «капіталу», так і чинити протилежну дію. Все це вкладається у його «роль імператора». Водночас «роль» не завжди реалізується у повній мірі, адже імператор має двояке ставлення щодо своїх функцій, щоразу аналізуючи і переосмислюючи їх.

Метою цієї наукової розвідки є дослідження ролі «імператора» і топосу «міста-столиці» у конструюванні символічної структури роману Рушді «Флорентійська чарівниця». Продуктивними для аналізу особливостей моделювання художнього простору та окреслення типових ознак топосу є концепції хронотопу Михайла Бахтіна («Форми часу та хронотоп у романі»). У трактуванні міста як певної соціальної структури і символічної системи, для розвитку якої необхідне виконання ритуалів, а також в означенняі ролі «імператора» у символічній системі виходимо з ідей французьких філософів П'єра Бурдьє, Мішеля Фуко і Гі Дебора.

Основна дія роману «Флорентійська чарівниця» відбувається у палаці імператора Акбара та у місті-столиці імперії - Сикрі. При цьому, топос взаємопровокується суб'єктами: тобто місто саме по собі не може існувати без суб'єктів, і суб'єкт як такий не можливий без міста. «Топос» і «суб'єкт» утворюють єдину символічну систему. Невід'ємним компонентом ідеєобразу Сикри як частини символічної системи, створеної іiі мешканцями, постає «вода». Наділена символічною роллю, вода у романі - це не тільки фізичний елемент його художнього простору, а й образна складова метафоричної мови: «В останньому присмерку озера блиск біля підніжжя міста-палацу здавався морем розлитого золота. Подорожній, їдучи шляхом у прозахідному сонці, а подорожній саме їхав шляхом уздовж озера, міг подумати, що він наближається до трону неймовірно багатого монарха, який аби зачарувати і викликати благоговійний страх у прибульців, дозволяв собі вихлюпнути у величезні скарби у велетенську земну улоговину. Золоте озеро, аж ніяк не мале, було краплею води 
у морі його багатства, тож подорожній навіть думкою не міг осягнути величі материнського океану! <..> А що коли за міськими мурами, думав подорожній, постане фонтан вічної молодости, а неподалік - легендарні ворота Земного Раю?» [5, с. 7]. Так розпочинається роман «Флорентійська чарівниця». Охарактеризована «перехідністю», «мінливістю» вода представляє живий організм, життєдайною образністю наповнює вона і соціальний простір: «...немає нічого складнішого, аніж вийти 3 матеріалізованого соціального простору, щоб осмислити його саме на відміну від соціального простору. I це тим паче вірно, що соціальний простір як такий схильний до того, щоб дозволяти бачити себе у формі просторових схем, а повсюдно використана для розмов про соціальний простір мова рясніє метафорами, запозиченими 3 фізичного простору» [2, с. 53]. Абсолютна метафоризація простору у романі вказує на те, що суб'єкти цілковито адаптовані у цій системі, і намагаються ідентифікуватись 3 фізичним простором, вони олюднють речі, що їх оточують: «Без води ми - ніщо. Навіть імператор, позбавлений води, дуже швидко перетвориться на порох. Вода - це справжня імператриця, а ми всі - іiі раби» [5, с. 281]. Вкінці роману крах міста-столиці асоціюється з пересохлим озером, з його своєрідною смертю.

У системі художнього світу роману «Флорентійська чарівниця» імператор Акбар займає виключну роль 3-поміж інших персонажів-суб'єктів. Ця роль здобута ним у процесі боротьби, адже, як стверджує Гі Дебор, «суб'єкт може виникнути лише із суспільства, тобто з існуючої у ньому боротьби» [3, с. 23]. Шлях імператора на трон не був для нього безперешкодним, і він володіє монополією на насильство у суспільстві, правителем якого $\epsilon$, оскільки заволодів офіційним статусом. Така ситуація корелює з думкою французького соціолога П’єра Бурдьє про те, що «офіційна номінація або звання, наприклад ранг диплома, має цінність на будь-якому ринку, оскільки офіційне визначення офіційної ідентичності вириває своїх володарів із символічної боротьби всіх з усіма, наділяючи своїх агентів дозволеною, визнаною усіма, універсальною перспективою» [2, с. 28]. Піддані сприймають імператора Акбара з тієї ж перспективи, як і його предків. На це, зокрема, вказує епізод про заборону голосно розмовляти у місті під час того, як у ньому знаходиться імператор: «Глиняне місто любило свого імператора і наполягало на цьому, проте наполягало мовчки, бо слова складались із забороненої матерії - звуку. Коли ж імператор черговий раз вирушав у похід (а походи ніколи не закінчувались і завжди були переможними) $<\ldots>$ звучали сурми і сміх, люди нарешті могли розповісти одне одному все те, про що були змушені мовчати впродовж місяців поспіль» $[5$, с. 26]. I хоча тривале будівництво міста-столиці імперії вказує на факт оновлення, в іiі фундамент також закладені уявлення минулих правителів, які закріпились у свідомості підданих: «Будівництво міста завершилось до імператорового сорокаріччя. Минуло дванадцять гарячих років надсадної праці, але в імператора вже давно склалось враження, ніби місто зводилось само собою, рік за роком, ніби за помахом чарівної палички. Адже діяла заборона міністра праці на здійснення найменших будівельних робіт під час перебування імператора у новій столиці» $[5$, с. 25$]$. 
Щоправда, Акбар частково сприймається як відсторонений від насильницького апарату, створюваного його попередниками впродовж століть. На таку думку наштовхують числені рефлексії цього персонажа, пов'язані з ідентифікацією і пошуком ідеальної форми правління, яка, щоправда, практично майже не реалізується. Лише згодом Акбар спробує змінити образ правителя, 3 яким його асоціюють, і тоді: «Місто вибухнуло радісним гумором. Того дня стало зрозумілим, що на троні сидів інший тип короля і що тепер геть усе в світі зміниться» [5, с. 27]. Суб'єкт, прикріплений до певного місця, ідентифікує себе з ним, так само і Акбар пов'язує себе зі своєю столицею. Навіть пересихання озера, єдиного джерела води для всього міста, він порівнює зі своїми невдачами: «Упродовж усього подальшого життя імператор вірив, що це незбагненне явище із зникненням озера у Фатегпур Сикрі було справою рук іноземця, якого він несправедливо зневажив і не наважувався прийняти до свого кола, аж поки вже не стало запізно <..> Це була найнищівніша Акбарова поразка; але не фатальна» [5, с. 281].

Місто Сикра має чітку структуру, яка відображає його ієрархію, що за своєю природою нічим не відрізняється від архаїчної структури, адже, як стверджує П. Бурдьє, «соціальні агенти, а також предмети, присвоєні агентами, а відтак конституйовані як власність, поміщені в якесь місце соціального простору, яке може бути охарактеризоване через його відносне положення щодо інших місць (вище, нижче, між і т. д.) і через дистанцію, яка відокремлює це місце від інших. Насправді, соціальний простір прагне перетворитися більшменш у фізичний простір за допомогою віддалення або депортації деяких людей - операцій неминуче дуже дорогих» [2, с. 50]. У романі Рушді воїнам, наприклад, «не дозволялось заходити на територію палаців, і вони отаборились біля підніжжя королівського пагорба» [5, с. 9]; «величезна криниця, а над нею неймовірно складні і великі водогінні механізми, що обслуговували багатокупольний палац на пагорбі» знаходилася за вежею з бивнями [5, с. 10]. Інші архітектурні споруди - місця масових зібрань, базари, зокрема і шахрайський базар, та дім розпусти - були розташовані ще далі від центрального палацу. Тому на мандрівника, який прибув у Сикру, очікували справжні перешкоди 3 наближенням до палацу. Так, згодом чужинцю, Магору Дель'Амору, що подолав довгий шлях аби опинитись у цьому місці, вдасться потрапити у палац $\mathrm{i}$ отримати прихильність імператора лише вдавшись до хитрощів $\mathrm{i}$ допомоги жінки з дому розпусти, яка раніше працювала при дворі.

За словами П. Бурьє, «столиця [la capitale], яка - принаймні у Франції - $\epsilon$ місцем капіталу [le capital], тобто місцем у фізичному просторі, де сконцентровані вищі позиції всіх полів і велика частина агентів, що займають ці панівні позиції. Відтак, столиця не може мислитися інакше, як у відповідності до провінції, яка не має нічого, крім позбавлення (відносного) і столичності, і капіталу» $[2$, с. 55]. У «Флорентійській чарівниці» Рушді ісрархія столиці Сикри із імператорським палацом як центром представляє у собі основний «капітал» імперії Акбара. При цьому імператор виступає хранителем цього капіталу і тим, хто розподіляє «блага». Імператор віддаляє або наближає до себе певних підданих: ця дія символічно вказує на залучення суб'єкта до капіталу. П. Бурьє пояснює ці дії так: «...незначне занесення у тіло структур соціального порядку, 
без сумніву, здійснюється значною мірою за допомогою переміщення і руху тіла, пози і положення тіла, які ці соціальні структури, конвертовані в просторові структури, організують і соціально кваліфікують як підйом або занепад, вхід (включення) або вихід (виключення), наближення або віддалення щодо центрального і цінного місця» [2, с. 51].

Найціннішим місцем у Сикрі вважається трон імператора, щодо якого спрямовані бажання його сина Саліма. Бажаним $є$ він і для чужинця Магора Дель'Амора, який прибуває до імператора, щоб переконати його, що є його дядьком. Потрапивши до столиці, Магор одразу наголошує на її багатстваі та щедрості правителя. Проте «центр» уміщує у собі і найбільший контроль: так, 3 наближенням до трону чужинець долає кожного разу все сильнішу варту, яка виставлена охороняти певну межу. Якщо «центр» вважається найбільш контрольованим місцем, згустком найконцентрованішої реалізації взаємин суб'єкта та влади, то сільська місцевість, околиці міста-столиці, показана як місце для задоволення. Акбар часто здійснює прогулянки за межі міста, в одну з яких він запрошує і чужинця Магора Дель'Амора, історія взаємин між якими складає одну із сюжетних ліній роману.

Довгий час імператор рефлексує про можливість віднайти ту людину, 3 якою зможе спілкуватись на рівних. На якийсь час цією людиною для нього стає Магор. Магор Дель'Амор набуває ролі виразника ідей правителя, які не можуть бути реалізовані через його імператорський статус, але можуть бути проговорені вустами іншого, і це викликає у нього насолоду. Водночас імператор не ділиться з Магором своєю владою, яка уособлює у собі капітал, він витримує дистанцію і діє обережно: чужинець не мешкає у палаці, його з різною частотою запрошують у палац. Ця ситуація художньо реалізує ідею П. Бурдьє, який зауважує: «Реалізований фізично соціальний простір є розподілом у фізичному просторі різних видів благ і послуг, а також індивідуальних агентів i груп, локалізованих фізично (як тіла, прив'язані до постійного місця: постійне місце проживання або головне місце проживання), та тих, що володіє можливостями присвоєння цих більш-менш значних благ і послуг (в залежності від наявного у них капіталу, а також від фізичної дистанції, яка відділяе від цих благ, яка сама в свою чергу залежить від їх капіталу)» [2, с. 54]. Так як Магор не має постійного місця проживання, його частка «блага» постійно варіюється. У палаці імператор наділяє його певним «благом», що презентує його довіру у справах імперії, а чужинець висловлює досить слушні думки та поради, чим здобуває прихильність Акбара, адже «символічний капітал - це довіра, влада, надана тим, хто отримав достатньо визнання, щоб бути у змозі вселяти визнання» [2, с. 84]. Передавши капітал довіри Магору, імператор усвідомлює, що таким чином Магор викликатиме довіру і в його народу: «Могол Кохання $\langle\ldots>$ мав успіх серед народу $\langle\ldots>$ Народ також знав, що сини - це імператорові розчарування. А це спричинило проблематичність майбутнього династії» [5, c. 254].

Імператор Акбар представляє собою суб'єкта, який ставиться до свого мандату діалектично. 3 одного боку, імператор репрезентує «роль», за якою закріплені сталі якості і функції: те, яким повинен бути імператор. Роль імператора містить у собі алгоритм поведінки, що обмежує Акбара як індиві- 
дуальність, не дозволяє йому у повній мірі реалізувати свої особисті якості. «Імператор» як роль реалізується через мову, на чому наголошує і П. Бурдьє: «Символічна влада як влада засновувати даність через висловлювання, влада змушувати бачити і вірити, стверджувати чи змінювати бачення світу i, відтак, вплив на світ, а значить, сам світ - це влада квазімагічна, яка завдяки ефекту мобілізації дозволяє отримати еквівалент того, що досягається силою (фізичною чи економічною), але лише за умови, що ця влада визнана, тобто не сприймається як свавілля» [2, с. 95]. Мова імператора у романі Рушді свідчить про те, що він приймає на себе символічну роль, жодним чином не виказуючи власних почуттів, які часом діаметрально-протилежні до того, що він висловлює. 3 іншого боку, свідомість Акбара продукує думки, що виявляють його світоглядні сумніви. Через усталені віками уявлення, він не наважується публічно озвучити їх, доручаючи це зробити чужинцю, і в такий спосіб реалізувати наміри щодо розбудови своєї імперії, а відтак і реалізувати насолоду імператора. Тому виникає дисонанс між зовнішнім мовленням, наказовістю у висловлюваннях, спрямованих супроти підданих, і внутрішнім мовленням, думками, в яких виважуються «накази» та їх правильність чи неправильність: «Знову ж таки, він ще раз поринув у суперечності. Він не хоче бути божеством, але вірить у справедливість своєї влади, своєї абсолютної влади, а тоді, згідно 3 його вірою, ця дивна ідея про доброчесність непокори, що якимось чином проникла у його свідомість, $є$ не що інше, як бунтарство. Це - невідворотний висновок, до якого доходить кожен тверезо мислячий принц <..> Розбіжності завжди існують, і завжди відбуваються страти та самогубства, але незгоду можна припинити, i це може зробити його кулак. Але як бути з внутрішнім голосом, що шепоче щоранку про гармонію, це не містична безглуздість всілюди-є-одним, але інша дивна думка» [5, с. 249].

Акбар не $\epsilon$ цілісністю, у ньому протистоять один одному імператор і людина: він перебуває у сумнівах, викликаних діями «імператора», який повинен служити на «благо» імперії, та моральним боком цих дій, що і провокує сум'яття. Акбар не $\epsilon$ цілковито підпорядкований «ролі» імператора, але механізм, за яким відбувається цей процес, нагадує психологічний процес переходу від достовірності до упевненості через сумнів та тривогу. «Роль» виступає своєрідним документом, але за допомогою сумніву Акбар частково дистанцією себе від цієї ролі, зберігаючи «ілюзію дистанції щодо усіх занять» [2, с. 133]. Проте дії імператора вказують на те, що він, насправді, не прагне відійти від своєї ролі чи прийняти іншу поведінку. Таку ситуацію П. Бурдьє коментує так: «...якби від того, що я підтримую існування цієї ролі, я не виходив би постійно за іiі рамки, не конституював би самого себе як того, хто ніби зайшов за інший бік свого становища» [2, с. 133]. Як результат внутрішніх вагань Акбара постає вибір між «я» і «ми», а також будівництвом палацу, де всі зможуть вільно виражати свої думки. Вибір стає очевидним, коли Акбар усвідомлює той факт, що абсолютна влада підпорядкована не йому, а «ролі імператора». Для того щоб «говорити» імператору, потрібно бути уповноваженим народом, а той визнає лише сформовану століттями «роль». Змодельована Рушді ситуація художньо ілюструє тезу П. Бурдьє: «...я є групою, тобто колективним примусом, примусом колективу щодо кожного його члена, я - людина, що стала 
колективом, й одночасно я той, хто маніпулює групою від імені самої цієї групи; я посилаюсь на групу, яка дозволяє мені здійснювати щодо неї примус» [2, c. 169].

Отже, Акбар може функціонувати у соціальній системі, лише якщо активує «роль», яка корелюватиме із загальноприйнятим у цій системі. Гі Дебор пояснює це так: «Нав’язаний в ії виставі образ блага вбирає в себе усю повноту того, що існує як офіційно визнане, i, як правило, концентрується на одній людині - гаранті іï тоталітарної згуртованості. 3 цією абсолютною зіркою кожен повинен або магічно ототожнити себе, або зникнути» [3, с. 26]. Тобто для реалізації себе у цій соціальній системі імператору потрібно відповідати певним критеріям «ролі», і лише тоді він отримає загальне схвалення. Ці критерії втілені в оточенні Акбара, яке вимагає конкретний стиль правління: «Чистою залишалась лишень уявна королева, і якось вона розповіла Акбарові про злигодні, яких зазнали люди через бажання запопадливих начальників догодити Акбару» [5, с. 27]. Відтак, насильство криється не у самій особі імператора, а в його оточенні та «ролі», які вимагають насильницькі дії, формуючи «ефект оракула» (поняття П. Будрьє), тобто «експлуатацію трансцендентності групи щодо індивіда» [2, с. 169]. «Роль» надає Акбару привілеї у виконанні ритуалів, передбачених системою, в якій він функціонує, це зокрема: можливість знищувати своїх ворогів без попереднього узгодження із суспільством і можливість постати божеством в очах своїх підданих (роман містить декілька згадок про зцілення імператором).

Французький філософ Мішель Фуко у праці «Наглядати та карати» пише: «Чим більше у людини влади або привілеїв, тим більше вона виділяється як індивід в ритуалах, дискурсах і пластичних уявленнях» [4, с. 235]. Свій «привілей» імператор Акбар застосує вкінці роману, коли зі столиці щезне Магор; тоді як протягом усієї розповіді він радше наглядач, який спостерігає 3 найвищої точки, свого палацу: «Імператор тихенько сидів у Панч-Магалі на горішньому поверсі...» [5, с. 279]. За М. Фуко, «центральна точка повинна бути як джерелом всеосвітлюємого світла, так і місцем, де б зійшлось усе, що підлягає пізнанню: досконалим оком, від якого ніщо не вислизає, і центром, що притягає до себе всі погляди» [4, с. 212]. «Роль» імператора видається саме цим центром, що приковує до себе погляди, і це тільки підсилюється локусом палацу.

Водночас сум'яття Акбара і його схильність до насолоди, що заперечує його статусну «роль», похитує трон. У романі читаємо: «В туркестанській колонії, в перському секторі, а також у кварталі, де мешкають індійські мусульмани, відзначено певний рівень занепокоєння <..> У підпільному журналі Бадауні $<\ldots>$ було порушено питання про богохульства $<\ldots>$ Майже невловимі вухом вібрації могли серйозно зашкодити поважній репутації імператора або ж навіть похитнути його трон» [5, с. 263]. Врешті це призводить до катастрофи: місто стає зневодненим. Більшість його мешканців розходяться, будучи самі відповідальними за своє виживання: тепер вони - індивіди, вони перестають бути колективом. Один із заключних епізодів роману розповідає про останню ніч свити в імператорському палаці, коли у них з'являється можливість насолодитись його величчю. Натомість, наближення до імператора виявляє обман i 
видає ілюзорність системи, творцями якої виступали вони самі, поставивши на iі чолі Акбара. Адже, як слушно зауважує Гі Дебор, «кожний крах лідера тоталітарної влади виявляє ілюзорне співтовариство, яке його одностайно схвалювало і було всього лише скупченням самотностей, що не мало ілюзій» [3, с. 28].

Насправді, цілісність соціальної системи порушується вже тоді, коли у структурі міста-столиці з’являються нові «компоненти» - дзеркальні образидвійники із суміжними функціями. Це спричиняє кризу розрізнення і провокує домінування ототожнення. Одним із таких «компонентів» виступає Магор Дель’Амор, який у даній системі займає позицію суміжну до імператора. Хоча йому не вдається закріпитись у палаці обабіч Акбара (останній то наближає його до себе, довіряючи певні справи, то віддаляє від себе), Магор асоціюється 3 його «двійником», названий Моголом Кохання. Місцем, де він найчастіше перебуває, є Дім Сканди, будинок розпусти: «Він відмовився від знайденої для нього функціонерами Акбара бюрократичної посади, і мешкав у Домі Сканди із Костомахою та Периною, повністю присвятивши себе роботі з відвідувачами закладу» [5, с. 278]. (Важливо, що цьому місцю сам імператор надає преференції після випадку, коли на Сикру зійшла епідемія скарг його мешканців, а ситуацію вдалось владнати за допомогою жінок з дому розпусти: «Відтоді будинок Костомахи й Перини став єдиним нічним закладом, який одержав особисту імператорську печатку, а самі жінки стали почесними радниками короля» [5, с. 164]. Дім Сканди - це також образ-двійник: «бордель» - дзеркальне відображення імператорського палацу. Ці два локуси мають своїх господарів, які певний час навіть взаємодіють.)

Народ схвально сприймає Магора на рівні з правителем. Можна стверджувати, що у такий спосіб імператор створює для себе заміну, аби у момент, коли суспільство наблизиться до найвищої точки кризи і більше не зможе існувати у своєму первісному стані, ця заміна могла зайняти його місце у ритуалі «жертвопринесення». Магор - це одиничне, яке потрібно принести у жертву замість цілісного та множинного суспільства. Така установка є визначальною для уявлень суб’єктів, які функціонують у символічній системі. Про це пише і Михайло Бахтін у праці «Форми часу і хронотопу в романі»: «Одинична річ стає замісником цілого: звідси заміщальна функція жертви (принесений у жертву плід фігурує як заміщення всього врожаю, тварина - заміщення всього стада або плоду і т.д.)» [1]. Магор повністю відповідає ознакам класичної «жертви»: він іноземець, у суспільстві Акбара він отримує статус, наближений до імператора (своєрідний блазень), якого певний час вважають «своїм», він навіть має стосунки 3 жінками 3 цього суспільства. За словами М. Бахтіна, «логіка заміщальної жертви: запобігти істинній ганьбі ганьбою фіктивною; згодом осмислюється як запобігання ,заздрості долі”» [1]. Відтак імператор, що відіграє у ритуалі найважливішу роль, обирає Магора як себезамінника для жертвопринесення.

Якщо імператор представляє «надлишок влади», то чужинець - ii брак. Особливо чітко це простежується в епізоді правосуддя над Магором: «Кайдани в пітьмі в'язниці гнітили його не менше ніж нерозказана історія. Його обвивало так багато кайданів, що іноді у темряві здавалося, ніби його запроторили у більше тіло - тіло залізної людини. Рухи були сковані. Про світло тільки 
мріялося. В'язницю було видовбано у природній скелі на пагорбі трохи нижче імператорських палаців, у камері стояло затхле тисячолітне повітря, i, мабуть, стільки ж років мали ті створіння, які повзали по його ступнях і волоссі, що залазили навіть у пах, - ці таргани-альбіноси, сліпі змії, безбарвні щури, водяні скорпіони і воші. Він помре, так і не розповівши своєї історії» [5, с. 72]. Мішель Фуко розділяє «короля» та «засудженого» на два полюси, вважаючи їх ролі суміжними: «На іншому полюсі можна уявити собі тіло засудженого; він теж має правовий статус, створює власний церемоніал і викликає цілий теоретичний дискурс, але не для того, щоб обгрунтувати «надлишок влади», що належить особистості правителя, а для того, щоб висловити «нестачу влади», що відбивається на тілах тих, хто піддається покаранню. У найтемнішій сфері політичного поля засуджений представляє симетричний перевернутий образ короля» [4, с. 38]. У в'язниці Магор страждає від фізичного та психологічного дискомфорту, тут же закріплюється за ним статус протилежний до імператора.

Як результат, соціальна система більше не може існувати у незмінному вигляді, вимагаючи докорінних змін. Стара система зазнає краху, що супроводжується втечею Магора 3 міста-столиці. За Акбаром йде лише «ядро» його суспільства, мешканці палацу та воїни, а решта народу розходиться просторами його імперії. Імператор втрачає народ, однак фінальний епізод доступу до «блага» та руйнування фантазму про цілісність та нерушимість символічної системи, суспільства Акбара, виконує функцію розрядки.

Отже, місто в романі Салмана Рушді «Флорентійська чарівниця» постає як соціальна структура і символічна система, яка провокує ієрархічні зв'язки, що вибудовуються у межах конкретного топосу міста-столиці Сикри. Ієрархія столиці як «капіталу» імперії найяскравіше відображена в імператорському палаці: імператор є хранителем капіталу і тим, хто розподіляє «блага», домінуючи у ритуалі жертвопринесення. Проте, як показано у дослідженні, поява дзеркальних образів-двійників із суміжними функціями приводить до кризи розрізнення i домінування ототожнення, а відтак руйнування цілісності суспільної системи, неможливості її існування у попередній формі.

\section{ЛІТЕРАТУРА}

1. Бахтин M. Формы времени и хронотопа в романе [Электронный ресурс] URL: http://philolog.petrsu.ru/filolog/lit/bahhron.pdf

2. Бурдье П. Социология социального пространства / пер. с фран. Москва : Институт экспериментальной социологии ; Санкт-Петербург : Алетейя, 2007. 288 с.

3. Дебор Г. Общество спектакля / пер. с фран. С. Офертаса и М. Якубович. Москва : Издательство Логос, 1999. 224 с.

4. Фуко М. Надзирать и наказывать / пер. с фран. Москва : Ад Маргинем Пресс, 2016. 416 с.

5. Рушді С. Флорентійська чарівниця / пер. 3 англ. Київ : Вид-во Жупанського, 2010. 288 с.

\section{REFERENCES}

1. Bakhtin, M. (1975), "Forms of time and chronotope in the novel" ["Formy vremeny $i$ khronotopa v romane"], available at: http://philolog.petrsu.ru/filolog/lit/bahhron.pdf (in Russian).

2. Bourdieu, P. (2007), Sociology of social space [Sotsiologiya sotsialnogo prostranstva], Aleteyya, Moscow, 288 p. (in Russian).

3. Debord, G. (1999), The society of the spectacle [Obschestvo spektaklya], Logos, Moscow, 224 p. (in Russian).

4. Foucault, M. (2016), Discipline and punish, trans. from French [Nadzirat i nakazyvat, per. z 
fran], Ad Marginem Press, Moscow, 416 p. (in Russian).

5. Rushdie, S. (2010), The Enchantress of Florence, trans. from English [Florentiyska charivnytsia, per. z anhl], Vyd-vo Zhupanskoho, Kyiv, 288 p. (in Ukrainian).

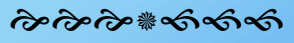

